\title{
МЕТОД СВЕНСОНА ДЛЯ ПОСТРОЕНИЯ КРИВОЙ ДОХОДНОСТИ "
}

\section{(ㄷ) 2021 Давкараев Султан Артурович}

студент, магистерская программа «Международные финансы (на английском языке)» Финансовый университет при Правительстве Российской Федерации, Россия, Москва E-mail:sult-good@mail.ru

Научный руководитель - Сидорова Марина Ильинична, д.э.н., профессор, Финансовый университет

В статье разбираются теоретические основы построения кривой бескупонной доходности с помощью модели Нельсона-Сигеля-Свенссона, а также продемонстрирован метод построения кривой на основе российских облигаций федерального займа.

Ключевые слова: модель Нельсона-Сигеля, модель Свенсона, кривая бескупонной доходности, облигации, спот, форвард.

Временная структура процентных ставок показывает взаимосвязь между процентной ставкой и сроком погашения безрисковых облигаций с нулевым купоном. Информация о временной структуре процентных ставок особенно важна для денежно-кредитной политики, поскольку содержит ожидания относительно будущей инфляции и процентных ставок.

Структура процентных ставок также важна для частных инвесторов и различных финансовых учреждений, таких как банки, хедж-фонды и пенсионные фонды. Почти все центральные банки мира самостоятельно считают структуру процентных ставок, при этом подходы к расчету могу отличаться. Финансовые институты используют структуру процентных ставок для поиска безрисковой ставки (например, в целях оценки для расчета средневзвешенной стоимости капитала). Спотовая ставка в структуре процентных ставок является более точным инструментом, чем доходность к погашению государственных облигаций. Доходность к погашению - это средняя ставка имеющихся спотовых ставок на момент расчета. Соответственно, единственная ситуация, когда доходность к погашению и спотовая ставка идентичны,когда существует горизонтальная структура процентных ставок. Если спотовые доходности имеют положительный наклон (чем выше срок погашения, тем выше ставка), они недооценены кривой доходности. В противном случае, если временная структура имеет отрицательный наклон, она будет переоценена доходностью к погашению.

Доходность безрисковых государственных облигаций с нулевым купоном, по сути, и является спот-доходностью, которая лежит в основе временной структуры процентных ставок. Однако, существует только определенное количество безрисковых облигаций с разным горизонтом по сроку. Именно по этой причине стало необходимо «искусственно» моделировать спотовые ставки из уже имеющихся безрисковых ставок. Существует множество техник для моделирования временной структуры, их можно разделить на две основные группы - это параметрические и сплайновые модели.

Центральные банки применяют разные методики для моделирования временной структуры, большинство использует параметрическую модель Нельсона-Сигеля. Россия также использует модифицированную версию НельсонаСигеля. Данная работа посвящена моделированию структуры процентных ставок методом Свенсона с помощью итеративной минимизации квадрата ошибки между рыночными безрисковыми ставками и теоретическими. Для итеративного процесса используется «Поиск Решений» с помощью метода приведенного градиента в «Microsoft Excel».

\footnotetext{
* Текст статьи приведен на русском языке в сокращенном виде. Полный текст статьи доступен на английском языке на странице 283.
} 


\section{Библиографический список}

1. Cox, John C., Jonathan E. Ingersoll Jr, and Stephen A. Ross. «A theory of the term structure of interest rates.» Theory of valuation. 2005. 129-164.

2. Martellini, Lionel, Philippe Priaulet, and Stéphane Priaulet. Fixed-income securities: valuation, risk management and portfolio strategies. Vol. 237. John Wiley \& Sons, 2003..

3. Diebold, Francis X., and Canlin Li. «Forecasting the term structure of government bond yields.» Journal of econometrics 130.2 (2006): 337-364.

4. Bundesbank, Deutsche. «Estimating the term structure of interest rates.» Monthly Report, October (1997): 61-66.

5. BIS (2005). Zero-coupon yield curves: Technical documentation. BIS Papers, 25. Bank for International Settlements.

6. Nelson, C., \& Siegel, A. (1987). Parsimonious modelling of yield curve. Journal of Business, 60, 473-489. doi:10.1086/296409

7. Svensson, L. E. (1994). Estimating and interpreting forward interest rates: Sweden 1992-1994, Centre for Economic Policy Research Discussion Paper 1051. doi:10.3168/jds.S0022-0302(94)77044-2.

8. Gilli, M., Große, S., \& Schumann, E. (2010). Calibrating the Nelson-Siegel-Svensson model, COMISEF Working Paper Series 31

9. MOEX. (2020, December 30). Zero-Coupon yield curve. Retrieved from https://www.moex.com/ru/marketdata/ indices/state/g-curve/.

10. Frontline Systems (2017b). Excel solver - GRG nonlinear solving method stopping conditions. Retrieved from https://www.solver.com/excel-solver-grg-nonlinear-solving-method-stopping-conditions.

11. Central Russian Bank. (2020, December 30). Deposit Standing Facility Interest Rates. Retrieved from https://cbr. ru/hd_base/deposit_base/.

12. Gambarov G, and I. Shevchuk. "Zero-coupon yield curve on the Russian Bond market”. Securities market, 3, (2006): 68-77. 


\title{
THE SVENSSON METHOD FOR THE YIELD CURVE SMOOTHING
}

\author{
(c) 2021 Davkaraev Sultan Arturovich \\ Student of International Finance (Master) \\ Financial University under the Government of the Russian Federation, Moscow, Russia \\ E-mail: sult-good@mail.ru
}

This paper focuses on the theoretical basis of constructing zero-coupon yield curve using the NelsonSiegel-Svensson method. The Russian Government Bonds are taken as an example for constructing the curve.

Keywords: The Nelson-Siegel curve, the Svensson curve, zero-coupon yield curve, bonds, spot-rate, forwardrate.

The term structure represents the relationship between the interest rates of zero-coupon bonds and their maturities [1]. The information regarding the term structure is important for the monetary policy and, as it contains the expectations about the future inflation and the interest rates. Also, it is useful for the individual investors and different financial institutions, such as banks, hedge funds and pension funds. In the case of the Central Banks, the term structure approach is adopted almost every country in the world (with different methods of calculating). In principle, it gives more precise information regarding the interest rates and provides the cross-country comparability of the results. In the case of the financial institutions, the term structure is used, for example, in determining the cost of capital for the valuation purposes [2]. The reason of using the term-structure rate, instead of the yield to maturity of the government bonds, is due to the nature of these two concepts. The yield to maturity is the "average" rate of different spot rates which depend on the date of the cash-inflows [3]. The price of the bond with coupon payments can be expressed from the yield to maturity point as follows:

$P=\frac{C}{(1+y)}+\frac{C}{(1+y)^{2}}+\cdots+\frac{C}{(1+y)^{n}}+\frac{N}{(1+y)^{n}}$ $=\sum_{1}^{n} \frac{C}{(1+y)^{n}}+\frac{N}{(1+y)^{n}}$

$\mathrm{C}$ and $\mathrm{N}$ in the formula (1) are the coupon and nominal price of the bond respectively. The yield in the denominator represents the average interest rate for different maturity dates. In practice, the yield is used when the bond is quoted by the Central Banks, as it is easy to interpret. Nevertheless, the yield curve almost never equals to the interest rate. The only

situation, when they are identical is if the constant discount rate applies to all maturities, i.e. when the horizontal term structure exists. When the interest rates have a positive slope (the higher the maturity, the higher the rate), they are underestimated by the yield curve. Otherwise, if the term structure has a negative slope it is overestimated by the curve. A graph (see Figure 1) illustrates the yield to maturity and the term structure for German government bonds for October 1996.

While the yield curve can be expressed directly, if the bond price and payments are known, the term structure is not that obvious. Government can issue some zero-coupon bonds and the quoted yield in a such case is already the recommended interest rate. However, in most cases there are only few zero-coupon bonds. That means, that the term structure should be calculated manually given the information of the issuance (price, yield, maturity date).

A lot of significant research has been made in order to find the best-fit model to extract the interest rates. Therefore, there are different techniques for the estimating the theoretical interest rates. Such models can be broadly categorized into parametric and spline-based methods, where the trade-off between the flexibility associated with the fitting to the yield curve and the smoothness of the curve exists [5]. The idea behind the parametric approach is the presence of a single function, that defines the term structure on the entire maturity period with special parameters. Spline-based models, in its turn, specifies not the single fixed function, that suits all maturities, but the so-called the "spline function", where the individual segments are jointed smoothly at the special knot-points. The Table 1 shows the approaches, that are used across different countries in order to estimate the term structure. 


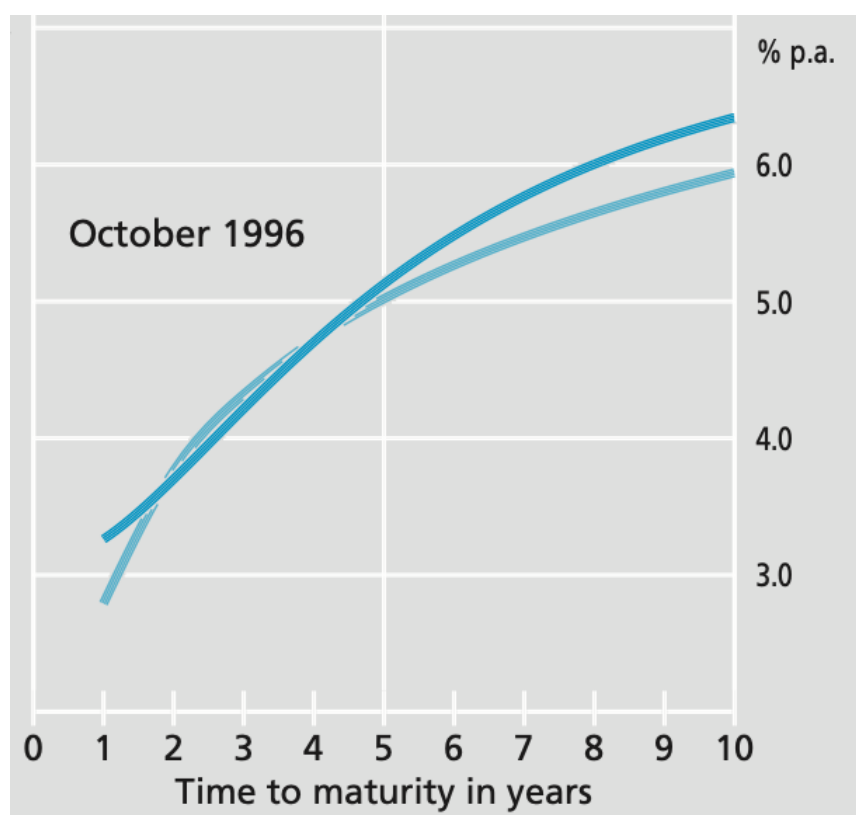

Figure 1. Comparison of the yield curve and the interest rates of Germany [4]

Table 1. The term structure estimation methods in different countries [5].

\begin{tabular}{|c|c|c|c|c|}
\hline Central bank & Estimation method & Minimised error & $\begin{array}{l}\text { Adjustments for tax } \\
\text { distortions }\end{array}$ & $\begin{array}{l}\text { Relevant maturity } \\
\text { spectrum }\end{array}$ \\
\hline Belgium & $\begin{array}{c}\text { Svensson or Nelson- } \\
\text { Siegel }\end{array}$ & Weighted prices & No & $\begin{array}{c}\text { Couple of days to } 16 \\
\text { years }\end{array}$ \\
\hline Canada & $\begin{array}{c}\text { Merrill Lynch } \\
\text { Exponential Spline }\end{array}$ & Weighted prices & $\begin{array}{l}\text { Effectively by } \\
\text { excluding bonds }\end{array}$ & 3 months to 30 years \\
\hline Finland & Nelson-Siegel & Weighted prices & No & 1 to 12 years \\
\hline France & $\begin{array}{c}\text { Svensson or Nelson- } \\
\text { Siegel }\end{array}$ & Weighted prices & No & Up to 10 years \\
\hline Germany & Svensson & Yields & No & 1 to 12 years \\
\hline Italy & Nelson-Siegel & Weighted prices & No & Up to 30 years \\
\hline Japan & Smoothing splines & Prices & $\begin{array}{l}\text { Effectively by price } \\
\text { adjustments for bills }\end{array}$ & 1 to 10 years \\
\hline Norway & Svensson & Yields & No & Up to 10 years \\
\hline Russia & $\begin{array}{l}\text { Nelson-Siegel with } \\
\text { additional terms }\end{array}$ & Yields & No & 2 months to 30 years \\
\hline Spain & Svensson & Weighted prices & Yes & Up to 10 years \\
\hline Sweden & $\begin{array}{l}\text { Smoothing splines } \\
\text { and Svensson }\end{array}$ & Yields & No & Up to 10 years \\
\hline Switzerland & Svensson & Yields & No & 1 to 30 years \\
\hline United Kingdom & VRP $^{*}$ & Yields & No & Up to 30 years \\
\hline United States & $\begin{array}{l}\text { Smoothing splines } \\
\text { (two curves) }\end{array}$ & $\begin{array}{c}\text { Bills: } \\
\text { weighted prices } \\
\text { Bonds: prices }\end{array}$ & No & Up to 10 years \\
\hline
\end{tabular}

* Variable penalty roughness approach is the "smoothing splines" type of approach implemented in the United Kingdom in 1998. 
Commonly used Svensson method is in the scope of this paper, because of the flexibility and the level of "smoothness" it provides. This parametric model and different variations of it are widely used in the European countries as well as in Russia.

The Svensson method is often called a NelsonSiegel-Svensson approach, because it is a modified version of the Nelson and Siegel model, which captured the relationship between the forward rates and the bond price data [6]:

$$
f_{m}=\beta_{1} \exp \left(\frac{-m}{\tau_{1}}\right)+\beta_{2} \exp \left(\frac{-m}{\tau_{1}}\right)
$$

In this equation (2) " $m$ " denotes time to maturity, $\beta_{1}, \beta_{2}, \tau_{1}$ are parameters that need to be estimated. By integrating (2) over the interval $[0, \mathrm{~m}]$ and dividing by $\mathrm{m}$, the following spot interest rate or zero-coupon rate $s_{m}$ can be obtained:

$$
\begin{aligned}
& s_{m}=\beta_{0}+\beta_{1}\left(\frac{1-\exp \left(\frac{-m}{\tau_{1}}\right)}{\left(\frac{m}{\tau_{1}}\right)}\right) \\
& +\beta_{2}\left(\frac{1-\exp \left(\frac{-m}{\tau_{1}}\right)}{\left(\frac{m}{\tau_{1}}\right)}-\exp \left(\frac{-m}{\tau_{1}}\right)\right)
\end{aligned}
$$

The limit of the spot rate with $\mathrm{m}$ approaching to zero is $\lim _{m \rightarrow 0} s_{m}=\beta_{0}$; when mapproaches to infinity the limit $\lim _{m \rightarrow \infty} s_{m}=\beta_{0}+\beta_{1}$ apply. Therefore, $\beta_{0}$ can be interpreted as long-term interest rate, whereas $\beta_{0}+\beta_{1}$ is the short-term rate. Parameters $\tau_{1}$ and $\beta_{2}$ do not have direct interpretation, though they impact the shape of the curve between mentioned limits. This approach, being a good approximation of the real interest rates, still does not reflect all possible shapes of the curve, which could be observed, for example, at times of great market uncertainty. Bearing this in mind, Svensson (1994) extended the model by adding one extra term, which is often called the second "hump" [7]. Two additional parameters $\tau_{2}$ and $\beta_{3}$ were involved, which gave a model more flexibility and precision. The extended instantaneous spot rate curve thus becomes:

$$
\begin{aligned}
& s_{m}=\beta_{0}+\beta_{1}\left(\frac{1-\exp \left(\frac{-m}{\tau_{1}}\right)}{\left(\frac{m}{\tau_{1}}\right)}\right) \\
& +\beta_{2}\left(\frac{1-\exp \left(\frac{-m}{\tau_{1}}\right)}{\left(\frac{m}{\tau_{1}}\right)}-\exp \left(\frac{-m}{\tau_{1}}\right)\right) \\
& +\beta_{3}\left(\frac{1-\exp \left(\frac{-m}{\tau_{2}}\right)}{\left(\frac{m}{\tau_{2}}\right)}-\exp \left(\frac{-m}{\tau_{2}}\right)\right)
\end{aligned}
$$

The term structure is calculated by the iterating process through minimizing the sum of squared residuals (RSS) between market yield-to-maturity and theoretical value [8]. Iteration helps to find the key beta and tau values which best apply to one particular date. Then, the Svensson curve is estimated by the formula for forward or spot rates mentioned above.

For the Russian market the essential data can be retrieved from Moscow exchange website (Table 2).

To minimize the square of difference between actual and theoretical YTM, the Solver of Microsoft Excel is used: Generalized Reduced Gradient (GRG) nonlinear algorithm optimizes non-linear problems such as extended Svensson function [10]. It goes over all variation of parameters $\beta$ and $\tau$ until the error is minimized. After 5 runs of the Solver, the following results for $\beta$ and $\tau$ are obtained on the date of 30/12/2020:

Table 3. Parameters $\beta$ and $\tau$ as for the 30 December 2020

\begin{tabular}{|l|l|}
\hline$\beta_{0}$ & 0.0683 \\
\hline$\beta_{1}$ & -0.0432 \\
\hline$\beta_{2}$ & -0.0000 \\
\hline$\beta_{3}$ & -0.0599 \\
\hline$\tau_{1}$ & 0.2611 \\
\hline$\tau_{2}$ & 1.0717 \\
\hline
\end{tabular}

It could be reasonably claimed, that based on $\beta_{0}$, the interest rate of a very distant future in Russia is $6.83 \%$, while a static value of instantaneous interest rate is $2.51 \%\left(\beta_{0}+\beta_{1}\right)$. The short-term rate $\left(\beta_{0}+\right.$ $\beta_{1}$ ) can be compared with the overnight deposit rate, which has the value of $3.25 \%$ on the date of 
Table 2. Russian Government Bonds' Yields on the 30 December 2020 [9].

\begin{tabular}{|c|c|c|}
\hline Maturity date & Yield to maturity (\%) & Maturity (years) \\
\hline $14 / 04 / 2021$ & $3.53 \%$ & 0.29 \\
\hline $18 / 08 / 2021$ & $4.05 \%$ & 0.63 \\
\hline $15 / 12 / 2021$ & $4.17 \%$ & 0.96 \\
\hline $20 / 07 / 2022$ & $4.28 \%$ & 1.56 \\
\hline $07 / 12 / 2022$ & $4.37 \%$ & 1.94 \\
\hline $25 / 01 / 2023$ & $4.43 \%$ & 2.08 \\
\hline $16 / 08 / 2023$ & $4.81 \%$ & 2.63 \\
\hline $04 / 10 / 2023$ & $4.77 \%$ & 2.77 \\
\hline $28 / 02 / 2024$ & $4.93 \%$ & 3.17 \\
\hline $17 / 07 / 2024$ & $5.06 \%$ & 3.56 \\
\hline $16 / 10 / 2024$ & $5.10 \%$ & 3.81 \\
\hline $16 / 07 / 2025$ & $5.37 \%$ & 4.56 \\
\hline $12 / 11 / 2025$ & $5.35 \%$ & 4.88 \\
\hline $16 / 09 / 2026$ & $5.51 \%$ & 5.73 \\
\hline $07 / 10 / 2026$ & $5.53 \%$ & 5.79 \\
\hline 03/02/2027 & $5.56 \%$ & 6.12 \\
\hline $06 / 10 / 2027$ & $5.72 \%$ & 6.79 \\
\hline $19 / 01 / 2028$ & $5.72 \%$ & 7.08 \\
\hline $17 / 05 / 2028$ & $5.80 \%$ & 7.4 \\
\hline $23 / 05 / 2029$ & $5.82 \%$ & 8.42 \\
\hline $10 / 04 / 2030$ & $5.91 \%$ & 9.31 \\
\hline $12 / 03 / 2031$ & $6.03 \%$ & 10.23 \\
\hline $17 / 09 / 2031$ & $6.03 \%$ & 10.75 \\
\hline $23 / 03 / 2033$ & $6.30 \%$ & 12.27 \\
\hline $10 / 05 / 2034$ & $6.36 \%$ & 13.4 \\
\hline $18 / 07 / 2035$ & $6.44 \%$ & 14.6 \\
\hline $16 / 03 / 2039$ & $6.46 \%$ & 18.27 \\
\hline
\end{tabular}

$30 / 12 / 2020$ [11]. Also, the long-term rate of $6.83 \%$ can be compared with zero-coupon yield curve for 30-year maturity bond calculated by the Moscow Exchange. They use the Nelson-Siegel method with the special correction factor. The rate is $6.96 \%$, which is slightly higher, than the calculated rate in this paper. The Figure 2 represents the results of the constructed Svensson curve and data points from the actual yields.

From the graph we can see, that the Svensson curve fits the observed data and might be used in estimating term structure in the Russian market. However, there are differences in values between approach in this paper and the Moscow Exchange methodology (Table 4).

It could be explained by the fact, that Moscow
Exchange modified the Nelson-Siegel approach in order to make the model more suitable for the Russian market due to its inefficiency and liquidity problems [12].

In conclusion, the Nelson-Siegel-Svensson model seems to be a good estimation of the yield curve. It fits data well, and the methodology looks as a quite friendly and widely available tool for the monetary policy institutions as well as for the market players. The interpretation of the parameters of the model also seems to be adequate, especially comparing them to the market values. Despite the complexity of the Russian market, the Svensson approach is still a suitable option for evaluating the term structure. 


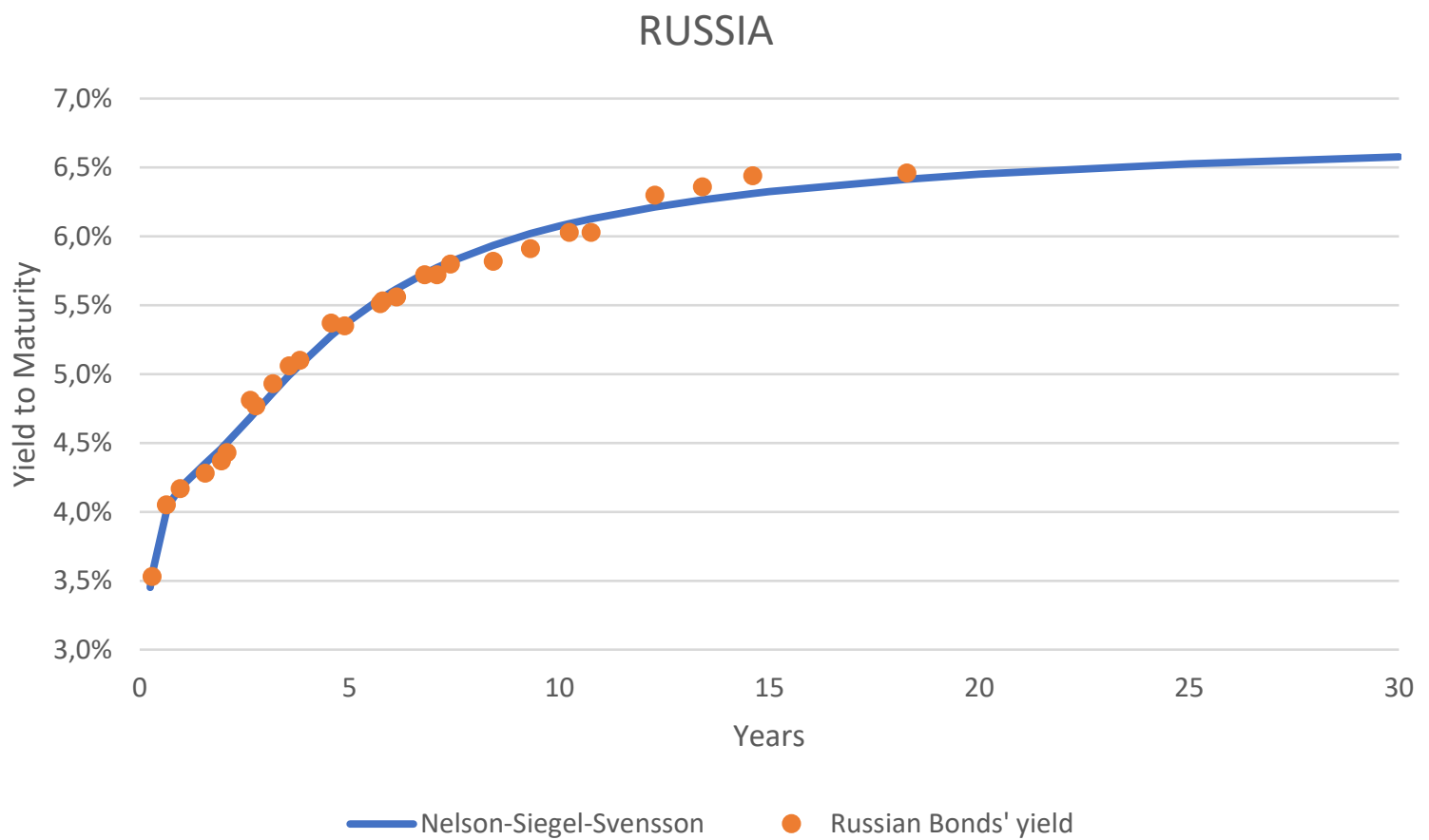

Figure 2. Russian market and NSS yield curve (30 December 2020).

Table 4. The difference between Svensson and Moscow Exchange methodology

\begin{tabular}{|l|c|c|c|c|c|c|c|c|c|c|c|}
\hline Years & 0.25 & 0.75 & 1 & 2 & 3 & 5 & 7 & 10 & 15 & 20 & 30 \\
\hline Svensson (\%) & 3.45 & 4.08 & 4.19 & 4.48 & 4.81 & 5.39 & 5.76 & 6.07 & 6.33 & 6.45 & 6.58 \\
\hline MoEX (\%) & 3.68 & 4.05 & 4.18 & 4.57 & 4.91 & 5.47 & 5.87 & 6.27 & 6.62 & 6.8 & 6.96 \\
\hline
\end{tabular}

\section{References}

1. Cox, John C., Jonathan E. Ingersoll Jr, and Stephen A. Ross. «A theory of the term structure of interest rates.» Theory of valuation. 2005. 129-164.

2. Martellini, Lionel, Philippe Priaulet, and Stéphane Priaulet. Fixed-income securities: valuation, risk management and portfolio strategies. Vol. 237. John Wiley \& Sons, 2003..

3. Diebold, Francis X., and Canlin Li. «Forecasting the term structure of government bond yields.» Journal of econometrics 130.2 (2006): 337-364.

4. Bundesbank, Deutsche. «Estimating the term structure of interest rates.» Monthly Report, October (1997): 61-66.

5. BIS (2005). Zero-coupon yield curves: Technical documentation. BIS Papers, 25. Bank for International Settlements.

6. Nelson, C., \& Siegel, A. (1987). Parsimonious modelling of yield curve. Journal of Business, 60, 473-489. doi:10.1086/296409

7. Svensson, L. E. (1994). Estimating and interpreting forward interest rates: Sweden 1992-1994, Centre for Economic Policy Research Discussion Paper 1051. doi:10.3168/jds.S0022-0302(94)77044-2.

8. Gilli, M., Große, S., \& Schumann, E. (2010). Calibrating the Nelson-Siegel-Svensson model, COMISEF Working Paper Series 31

9. MOEX. (2020, December 30). Zero-Coupon yield curve. Retrieved from https://www.moex.com/ru/marketdata/ indices/state/g-curve/.

10. Frontline Systems (2017b). Excel solver - GRG nonlinear solving method stopping conditions. Retrieved from https://www.solver.com/excel-solver-grg-nonlinear-solving-method-stopping-conditions.

11. Central Russian Bank. (2020, December 30). Deposit Standing Facility Interest Rates. Retrieved from https://cbr. $\mathrm{ru} / \mathrm{hd}$ _base/deposit_base/.

12. Gambarov G, and I. Shevchuk. "Zero-coupon yield curve on the Russian Bond market". Securities market, 3, (2006): 68-77. 